Danuta Opozda*

Lublin

\title{
Przebaczenie w rodzinie - implikacje pedagogiczne
}

Refleksja nad przebaczeniem posiada bogatą tradycję chrześcijańską oraz filozoficzną. Szczególne miejsce zajmuje w analizach filozofii moralnej, na gruncie której prowadzony jest szczegółowy namysł nad istotą i specyfiką przebaczenia jako ludzkiego fenomenu' ${ }^{1}$. Zainteresowanie przebaczeniem z racji jego siły „uzdrowienia” znajduje również właściwe uzasadnienie w obszarze teorii i praktyki terapeutycznej². Niektóre z konfliktów intrapsychicznych czy interpersonalnych mogą być rozwiązane lub ich skutki złagodzone $\mathrm{w}$ procesie postępowania psychoterapeutycznego kształtującego postawę przebaczenia. Problematyka przebaczenia stopniowo wyłania się jako przedmiot poznania oraz analiz $\mathrm{w}$ naukach społecznych i należy podkreślić, że jej ujmowanie ma coraz bardziej interdyscyplinarny charakter. Potrzebne jest również prowadzenie pedagogicznej refleksji nad przebaczeniem. Perspektywa pedagogiczna umiejscawia zagadnienia związane z przebaczeniem

* Dr hab. Danuta Opozda jest kierownikiem Katedry Pedagogiki Rodziny w Instytucie Pedagogiki Katolickiego Uniwersytetu Lubelskiego Jana Pawła II. Adres: Instytut Pedagogiki KUL, ul. Droga Męczenników Majdanka 70, 20-325 Lublin; e-mail: danan@kul.lublin.pl

${ }^{1}$ Zob.: Filozofia moralności. Wina, kara, wybaczenie, red. Jacek Hołówka (Warszawa: Fundacja Aletheia, 2000).

2 Zob.: Matthew Linn, Dennis Linn, Uzdrawianie ludzkich zranień (Kraków: Wydawnictwo M, 1993); Avis Clendenen, Martin Troy, Uzdrawiająca siła przebaczania (Kraków: Wydawnictwo WAM, 2004); Jerzy Mellibruda, Pułapka niewybaczonej krzywdy (Warszawa: Instytut Psychologii Zdrowia i Trzeźwości, 1995). 
w odniesieniu do rzeczywistości wychowania i relacji interpersonalnych zachodzących w zróżnicowanych środowiskach wychowawczych. W niniejszym artykule podjęta jest próba refleksji nad przebaczeniem w rodzinie z uwzględnieniem i wyeksponowaniem pedagogicznego namysłu. Pytaniem zasadniczym jest to, jakich kontekstów nabiera przebaczenie w świetle pedagogicznej oceny wychowania w rodzinie i dlaczego, z jakich powodów przebaczenie w przestrzeni życia małżeńsko-rodzinnego jest tak ważne dla przebiegu wychowania.

\section{Przebaczenie jako proces i postawa oraz jego pedagogiczne konteksty}

$\mathrm{Z}$ racji podjętego tematu istotne jest rozumienie przebaczenia, jako procesu i postawy w wymiarze jego relacyjności. Przebaczenie oznacza, że ktoś przestaje się gniewać na kogoś, puszcza coś w niepamięć i daruje mu winę Wybacza wyrządzoną krzywdę i nie wraca do sytuacji poniesionej szkody. Warto jednak zauważyć, że przebaczenie może dotyczyć nie tyko drugiej osoby, ale również może odnosić się do samego siebie. Są bowiem sytuacje, w których człowiek powinien niejako zmierzyć się z przebaczeniem samemu sobie.

Chociaż w indywidualnej sytuacji człowieka można gdzieś odnaleźć akt decyzji o przebaczeniu komuś, to jednak przebaczenie jest procesem rozciągłym w czasie, zwłaszcza gdy poczucie doznanej krzywdy dotyczy zdarzeń ważnych i zranienie jest bolesne oraz głęboko przeżywane. Wola i decyzja o przebaczeniu jest jedynie, i aż, elementem tego procesu. W proces przebaczenia zaangażowane są procesy emocjonalne, motywacyjne i intelektualne. Człowiek uświadamia sobie własne emocje w związku z doświadczaną krzywdą, niesprawiedliwością. Dostrzega znamiona tej trudnej, krzywdzącej sytuacji, która sama w sobie może być złożona i długotrwała. Nazywa, określa to, co go dotknęło i próbuje to zrozumieć, a także zwerbalizować. Przebaczenie rozumiane jako proces wymaga nowego spojrzenia na sytuację doznanej krzywdy. Wymaga dojrzałości i często pokonania własnych wewnętrznych barier. W tej atmosferze rodzi się wola przebaczenia. W literaturze przedmiotu zwraca się uwagę na etapowość procesu przebaczenia, między innymi wyróżniany jest etap wypierania się, gniewu, targowania się,

3 Słownik Języka Polskiego, red. Mieczysław Szymczak (Warszawa: Wydawnictwo Naukowe PWN, 1996), 999. 
depresji oraz akceptacji ${ }^{4}$. Wyodrębnienie etapów przebaczenia, ustalenie prawidłowości czy pewnych mechanizmów tego procesu oraz zmian dokonujących się w jednostce jest szczególnie istotne z punktu widzenia prowadzenia działań psychoterapeutycznych.

Procesowi przebaczenia towarzyszą kluczowe dla jego przebiegu czynniki, jak między innymi:

- właściwe rozumienie przebaczenia;

- uznanie ograniczenia człowieka złem;

- zdolność dostrzeżenia pozytywnych cech osoby, która była sprawcą krzywdy;

- zaangażowanie i dojrzałość religijna, która urzeczywistnia w istotny sposób gotowość i zdolności do przebaczenias.

Przebaczenie wymaga właściwego zrozumienia jego istoty. Nie jest zapomnieniem i wyparciem do podświadomości doznanej szkody. To zdolność świadomej rezygnacji z powracania do sytuacji krzywdy. Chociaż przebaczanie łączy się często $\mathrm{z}$ pojednaniem, to jednak samo pojednanie nie jest warunkiem koniecznym przebaczenia. Można bowiem darować komuś krzywdę - przebaczyć, a jednocześnie nie mieć szansy na pojednanie. I o ile pojednanie wymaga wzajemnego kontaktu, wymaga uzewnętrznienia, to przebaczenie może być procesem dokonującym się wewnątrz, intrapsychicznym, jednostronnym, nie zawsze ujawnionym wprost, chociażby na okoliczność niemożności spotkania się z krzywdzicielem.

Zrozumienie doświadczenia krzywdy i potrzeby przebaczenia ułatwia dostrzeżenie pozytywnych cech osoby, która doprowadziła do krzywdy i przyjęcie faktu, że w życiu człowiek popełnia błąd i jest ograniczony złem. Takie rozumienie i spojrzenie na sytuację bycia poszkodowanym ułatwia postawa chrześcijańska; postawa miłosierdzia wobec bliźniego. Podkreślić należy, że to właśnie głównie z tradycji chrześcijańskiej wywodzi się refleksja nad przebaczeniem będącym iście ludzkim aktem, procesem zachodzącym w relacjach międzyosobowych i postawą wobec drugiego człowieka.

${ }^{4}$ Stanisław Tokarski, Od przebaczenia do pojednania-psychologiczne uwarunkowania pojednania z Bogiem i ludźmi, http://www.psychologia.net.pl/artykul.php?level=327 (pobrano: 15.06.2016); Elizabeth Kübler-Ross, Rozmowy o śmierci i umieraniu (Poznań: Media Rodzina, 1998).

5 Zob. Aldona Król, „Wychowanie do przebaczenia”, w: Wychowanie chrześcijańskie między tradycja a współczesnością, red. Alina Rynio (Lublin: Wydawnictwo KUL, 2007), 432-433. 
Rozumienie przebaczenia jako procesu współwystępuje i łączy się z rozumieniem przebaczenia jako postawy wobec drugiego człowieka. Wskazuje to na wiele odwołań do zagadnień psychologicznych i pedagogicznych. Ukierunkowanie refleksji nad przebaczeniem rozumianym jako postawa implikuje istotne tematy z zakresu psychologii społecznej, dla której kategoria postawy jest jedną $\mathrm{z}$ centralnych ${ }^{6}$. $\mathrm{Z}$ punktu widzenia podejmowanej problematyki wydaje się jednak wystarczające podkreślenie, że przebaczenie $\mathrm{w}$ relacjach interpersonalnych $\mathrm{i}$ jednocześnie jako wewnętrzny proces dokonujący się w jednostce oznacza wskazanie na tradycyjne komponenty postaw: poznawczy, emocjonalny i behawioralny. Po pierwsze chodzi tu o poznawcze zaangażowanie $\mathrm{w}$ zrozumienie całości sytuacji: siebie jako osoby skrzywdzonej i drugiej osoby będącej sprawcą krzywdy oraz całego splotu okoliczności kontekstowych. Po drugie wskazuje na spektrum uczuć prowadzących między innymi od żalu, chęci zemsty, gniewu, smutku - generalnie uczuć negatywnych - do aktu miłosierdzia, darowania win i kary, aż po spokój i nawet życzliwość wobec krzywdziciela - ogólnie uczuć pozytywnych. Po trzecie postawę przebaczającą dopełnia działanie, zachowanie, czyn przebaczenia, który ma obserwowalne, behawioralne oznaki. Udział tych trzech komponentów gwarantuje zwartość i spójność postawy przebaczenia. Przebaczenie ujęte jako postawa odsłania bogatą problematykę psychopedagogiczną dotyczącą kształtowania postaw i zmiany postaw, a więc też szczególnego udziału procesów socjalizacji pierwotnej i wtórnej z wiodącym udziałem wychowania dziecka w rodzinie.

Nawet wstępne spojrzenie na przebaczenie jako proces i postawę pozwala, jak sądzę, wyeksponować przynajmniej trzy istotne pedagogicznie i ściśle powiązane ze sobą wątki, to jest:

- normatywność,

- relacyjność,

- kształtowanie postawy przebaczenia.

Normatywność odnosi nas do wartości, jako kluczowego pojęcia nierozerwalnie związanego z przebaczeniem z dwóch przynajmniej powodów. Otóż najpierw poczucie doznanej krzywdy wskazuje w odbiorze jednostki (osoby pokrzywdzonej) na naruszenie wobec niej nie tylko zasady sprawiedliwości, ale przede wszystkim pewnych norm i wartości ważnych w jej hierarchii. Zinterpretowanie jakiejś sytuacji w kategoriach doznawanej krzyw-

${ }^{6}$ Bogdan Wojcieszke, Człowiek wśród ludzi. Zarys psychologii społecznej (Warszawa: Wydawnictwo Naukowe SCHOLAR, 2002), 178-195. 
dy jest rezultatem rozdźwięku między tym, co zaszło, dzieje się i jest realne, a tym, co być powinno, jest oczekiwane i wyznaczone zasadami czy normami. Przy czym warto przywołać w tym miejscu rozróżnienie i jednocześnie zachodzącą relację między przebaczeniem i sprawiedliwością. Przebaczenie wykracza poza rozeznanie czegoś (sytuacji) w kategoriach sprawiedliwości. Jest w pewnym sensie rezygnacją z czegoś, co prawnie „należy się” krzywdzicielowi, czyli rezygnacją z kary, a - w odniesieniu do poszkodowanego jest rezygnacją z dochodzenia swoich praw i z zadośćuczynienia. W tym kontekście też inną płaszczyzną przywołania wartości w procesie przebaczenia jest wola przebaczenia, co oznacza zdystansowanie się do poczucia krzywdy i dostrzeżenie wartości w samym przebaczeniu. System wartości ostatecznie motywuje jednostkę do „darowania kar” i właściwego ,zapomnienia win”. Wzniesienie się ponad sytuację krzywdy jest urzeczywistnieniem wartości nadrzędnych związanych z szacunkiem do człowieka i jego godności mimo błędu i słabości, jakie posiada. Chociażby te dwa powody uzasadniają pedagogiczną potrzebę analizy przebaczenia uwzględniającą kontekst aksjologiczny, tak ważny zarówno w samym procesie przebaczania, jak i w procesie wychowania $\mathrm{z}$ uwagi na wiodącą rolę w wyznaczaniu celów wychowania i zasad wychowawczych ${ }^{7}$.

Proces przebaczania dokonuje się najczęściej w relacji z drugim człowiekiem, nawet jeśli nie jest ona wyrażona wprost, bezpośrednio. Przebaczyć drugiemu to także nawiązać z nim relację prawdziwie osobową, okazać pełnię człowieczeństwa. Do tego przysposabia nie tyle tendencja wrodzona lub reaktywność i wyuczony automatyzm, lecz umiejętność wypracowana, jako efekt sztuki wychowania i relacji wychowawczej między osobą wychowanka a wychowawcy. Uczenie przebaczania drugiemu człowiekowi lub samemu sobie dokonuje się poprzez wychowawcze uczestniczenie w relacji interpersonalnej. Prawidłowe relacje wychowawcze wspierają $\mathrm{w}$ istotny sposób kształtowanie postawy przebaczenia, gdyż są warunkiem transmisji wpływu wychowawczego.

Przebaczenie zatem jako proces i postawa niejako domaga się udziału wychowania z racji centralnego dla wychowania wymiaru aksjologicznego, wymiaru relacyjnego i znaczenia wychowania w kształtowaniu postaw.

${ }^{7}$ Zob. Marian Nowak, Pedagogiczny profil nauk o wychowaniu. Studium z odniesieniami do pedagogiki pielegniarstwa (Lublin: Wydawnictwo KUL, 2012). 


\section{Rodzina miejscem przebaczenia}

Istotny dla przebaczenia kontekst normatywny, relacyjny i kształtowania postaw jest także nieodzowny i znamienny w procesie wychowania w rodzinie. System wartości regulujący życie małżeńsko-rodzinne, specyfika relacji wewnątrzrodzinnych oraz znaczenie doświadczeń rodzinnych i procesu wychowania w kształtowaniu wszelkich postaw człowieka wobec otaczającej rzeczywistości są zagadnieniami podstawowymi w pedagogicznym opisie i rozumieniu rodziny. Rodzina jest najbardziej naturalnym, oczywistym miejscem urzeczywistniania się przebaczenia $\mathrm{w}$ imię przyjętych wartości, w codzienności relacji międzyludzkich i w procesie nabywania umiejętności przebaczania. Problematykę przebaczenia w odniesieniu do wychowania w rodzinie, zachowując pedagogiczną perspektywę, można rozważać w dwóch obszarach:

1. pierwszy skłania do refleksji - najogólniej rzecz ujmując - nad znaczeniem przebaczenia w funkcjonowaniu rodziny;

2. drugi obszar dotyczy wychowania w rodzinie do przebaczenia, czyli kształtowania postawy przebaczenia wobec drugiego człowieka i wobec samego siebie.

$\mathrm{W}$ odniesieniu do pierwszego obszaru znaczenie przebaczenia w rodzinie uwzględnia fakt, iż rodzina stanowi niezastępowalne środowisko wychowawcze, grupę wyróżniającą się bliskimi, bezpośrednimi i autentycznymi relacjami interpersonalnymi, stanowi wspólnotę osób tworzącą przestrzeń dla indywidualnego rozwoju jednostki, jak również realizacji wspólnych celów członków rodziny. W tym kontekście warto zwrócić uwagę przynajmniej na trzy aspekty:

1) przebaczenie $w$ rodzinie łączy się $z$ faktem, iż krzywdzicielem jest osoba bliska, a nie obcy (łatwiej uporać się z krzywdą doznaną od kogoś obcego);

2) przebaczenie $w$ rodzinie jest w szczególny sposób wpisane w relację (wyrządzona krzywda ma znaczenie nie tylko dla uczestników tej relacji, ale i dla całego systemu rodzinnego);

3) akt przebaczenia przekracza granice sztywnego myślenia o rodzinie w kategorii nieuniknionych mechanizmów i schematów zachowań, gdyż jest aktem osobowym.

Kolejno odnoszę się do powyższych kwestii.

Ad 1) Przebaczenie w rodzinie nabiera szczególnych znaczeń i kontekstów z uwagi na fakt, że dotyczy przebaczenia krzywdy doznanej od kogoś 
bliskiego (rodzic, współmałżonek, rodzeństwo), od kogoś, od kogo oczekuje się wsparcia, pomocy, troski i ochrony. Zdaniem Marii Braun-Gałkowskiej „Krzywda doznana od osoby bliskiej szczególnie boli, a jej skutki są tym bardziej doniosłe, że uczucia przeżywane przez ofiarę są sprzeczne: krzywdziciela kocha się i nienawidzi jednocześnie, dlatego też uczucia te są trudne do zniesienia i często spychane do podświadomości"». Jak dalej zwraca uwagę autorka, „Przedrostek «prze» mówi o tym, że jakaś czynność jest już dokonana np. przeczytać książkę, czyli skończyć czytanie. Prze-baczyć, znaczy przestać baczyć na to, co się stało. Przebaczenie jest więc zakończeniem koncentracji na doznanej krzywdzie, pójściem dalej. Przebaczenie jest aktem woli. Jest dowodem siły i wielkoduszności"9.

Tłumienie uczuć może w rodzinie prowadzić do kolejnych nieporozumień, konfliktów i zaburzeń w relacjach interpersonalnych. Ani zaprzeczanie krzywdzie, ani pochopne przebaczenie, zwłaszcza dotyczące niebłahych zdarzeń, nie rozwiązuje problemu. M. Braun-Gałkowska zwraca uwagę, że przebaczenie w rodzinie dokonuje się stopniowo i wymaga potrzebnego czasu oraz wyróżnia następujące jego etapy:

- dopuszczenia krzywdy do świadomości;

- budzenia motywacji do dokonania przebaczenia;

- postanowienia i decyzji o przebaczeniu.

$\mathrm{Na}$ każdym z tych etapów wskazana jest wewnętrzna refleksja, rozpoznanie sytuacji, rozmowa z krzywdzicielem o ile to możliwe, czasami wskazane jest wsparcie terapeuty lub innej osoby, która pomoże spojrzeć na sytuację z innej perspektywy i dystansu.

Ad 2) Przebaczenie wpisane w codzienność życia rodzinnego i nieustanne relacje wewnątrzrodzinne służyć może utrzymaniu i rozwojowi więzi w rodzinie, integracji małżeństwa i rodziny, zachowaniu i umacnianiu wspólnotowości rodziny. Rodzina jako system powiązań i złożony układ relacji międzygeneracyjnych jest podstawową przestrzenią urzeczywistniania przebaczenia. Relacja małżeńska, relacja między rodzicem a dzieckiem, relacje braterskie czy też inne możliwe międzypokoleniowe relacje w rodzinie są miejscem na wzajemne wybaczenie. Istotą przebaczenia w rodzinie jest wzajemność. Właśnie w rodzinie przebaczenie powinno dokonywać się w relacji, powinno mieć charakter dwustronny. Zauważa się, że dwustronne

${ }^{8}$ Maria Braun-Gałkowska, Psychologia domowa (Lublin: Wydawnictwo KUL, 2008), 54.

9 Tamże, 56. 
przebaczenie pociąga za sobą znacznie więcej korzyści niż jednostronne ${ }^{10}$. Jednostronne przebaczenie oznacza jedynie niechowanie urazy, żalu, pretensji do krzywdziciela. Pomijam w tym miejscu bogatą problematykę związaną z przepracowaniem uczuć negatywnych wiążących się z sytuacją krzywdy czy też zaprzeczaniem tym uczuciom, co de facto nie stanowi przebaczenia.

Przebaczenie w rodzinie domaga się wzajemności przede wszystkim $\mathrm{z}$ uwagi na znaczenie, jakie posiada dla naprawy relacji międzyosobowych i jakości codziennego wspólnego funkcjonowania członków rodziny, która tworzy przecież wzajemnie powiązany system. Dwustronność przebaczenia w rodzinie przede wszystkim może oznaczać:

- obustronne zaangażowanie,

- wzajemną współpracę,

- próbę wspólnego rozpoznania i ujednolicenia spojrzenia na sytuację krzywdy,

- wzrost zrozumienia i empatii,

- poczucie zbliżenia i lepszego poznania,

- pojednanie,

- poprawienie wzajemnej relacji,

- poprawienie relacji w całym systemie rodzinnym.

Ogólnie więc przebaczenie jest warunkiem (nie jedynym) dobrych relacji w rodzinie, nacechowanych serdecznością, życzliwością i akceptacją osób (choć czasami dezaprobatą dla ich zachowań). W takich warunkach najlepiej dokonuje się transmisja wpływów wychowawczych, kształtowanie właściwych postaw i rozwój osoby. Wychowanie bowiem wymaga prawidłowych relacji, a w te z kolei, zwłaszcza gdy odznaczają się codziennością i długotrwałością, wpisane jest przebaczenie. W rodzinie czasami przejść trzeba ponad sytuacje drobne, nie chować urazy i nie wzmacniać u siebie lub innych poczucia krzywdy. Czasami zaś należy i wręcz koniecznością jest komunikowanie o sytuacji doznawanej krzywdy, rozpoznanie jej, nazwanie i podjęcie próby zmiany. Do wyjątkowych sytuacji należą tu trudne sprawy związane z wszelkiego rodzaju przemocą w rodzinie.

Ad. 3) Warto zaznaczyć jeszcze jeden aspekt przebaczenia w rodzinie. Otóż przebaczenie ma osobowy wymiar - dotyczy osoby, ma charakter podmiotowy, można rzec subiektywny. Choć dokonuje się w relacji interpersonalnej i systemie rodzinnym, to jednak najpierw musi dokonać się w jed-

${ }^{10}$ Elżbieta Trepkowska, „Dwie koncepcje przebaczenia. Przebaczenie jako warunek i jako element procesu naprawy relacji międzyludzkich”, Etyka 42 (2009): 121-135. 
nostce - osobie doznającej krzywdy. Jako akt silnie zindywidualizowany i zależny od woli jednostki. W jakimś sensie wymyka się opisom mechanizmów, a nawet może wymykać się pewnym „sztywnym” prawidłowościom funkcjonowania rodziny i dla kogoś z zewnątrz może okazać się wręcz niezrozumiały. Jest niejako „nieprzewidywalny”, wykraczający poza schematyczne rozumienie rodziny i reaktywność zachowań jej członków. Wymaga to spojrzenia na rodzinę zawsze w zindywidualizowany sposób i postawy fenomenologicznej otwartości.

Drugi obszar przebaczenia $\mathrm{w}$ rodzinie ściśle wiąże się z rodziną jako środowiskiem wychowawczym, które można określić mianem „,szkoły przebaczenia". W rodzinie dziecko uczy się przebaczenia drugiemu, rodzina kształtuje postawę przebaczenia. Chociaż w odniesieniu do pojęcia ,przebaczenie” stosowane są sformułowania typu „uczyć”, „kształtować”, to jednak należy podkreślić, że chodzi tu o nieustanny i złożony proces rozwijania sprawności i umiejętności przebaczania. Zdolność do przebaczenia nie może więc być jedynie deklaratywną zasadą życia, lecz czynem, działaniem człowieka w relacji z drugim, jako rezultat aktu jego wolnej woli i szacunku do drugiego.

Pojawia się więc pytanie, jak wychowanie w rodzinie może rozwijać tę zdolność i co jest szczególnie ważne i specyficzne w tym procesie. Można przyjąć za podstawę szukania odpowiedzi na te pytania ogólne wskazania dotyczące wychowania moralnego i wychowania religijnego w rodzinie. Anomia moralna i okres areligijny pierwszego okresu postnatalnego sugeruje znaczący udział rodziny w rozwoju moralności i życia duchowego dziecka, a potem młodego człowieka (pamiętając, że obie te sfery rozwojowe odznaczać się mogą nieliniowością).

Proces wychowania do przebaczania wpisuje się w całość czynności i oddziaływań wychowawczych związanych ściśle z wychowaniem moralnym $\mathrm{w}$ rodzinie. Wychowanie to jest kluczowym oddziaływaniem rodziny na jednostkę, wspiera nie tylko rozwój moralny, rozwój osobowości, ale prowadzi do dojrzałości, ,rodzi do życia duchowego"11 i rozwija człowieczeństwo. „Wychowanie moralne jest [...] pytaniem nie tyle o zasady zmiany wyznawanych norm moralnych (do czego prowadziłoby kształcenie), ile dotyczy sposobów zmiany moralnej jakości czynów człowieka (zakładającej

11 Józef Wilk, Pedagogika rodziny. Zagadnienia wybrane (Lublin: Wydawnictwo Poligrafia Salezjańska, 2002), 7. 
oczywiście zmiany w rozumieniu moralnych aspektów poszczególnych czynów)"12.

Fundamentem rozwoju moralności i religijności człowieka jest jego tak zwana zdrowa osobowość, kształtująca się już w okresie prenatalnym. Jeżeli zatem proces wychowania do przebaczenia jest szczególnie włączony w wychowanie moralne i religijne $\mathrm{w}$ rodzinie, to podstawą tego procesu jest całokształt prawidłowych relacji wewnątrzrodzinnych prowadzących do rozwoju osobowości dziecka.

Zauważyć należy, że w tych obszarach oddziaływań i transmisji wpływu wychowawczego rodziny ważne miejsce zajmują wartości wyznaczające jakość życia rodziny. Wychowanie w rodzinie jest wychowaniem poprzez wartości i wychowaniem ku wartościom ${ }^{13}$. Rodzice wychowują dziecko zgodnie $\mathrm{z}$ preferowanymi w życiu wartościami. To one w znacznym stopniu określają styl życia rodziny, wzajemne odniesienia, podejmowane decyzje i dokonywane wybory. Rodzice żyją według przyjętych wartości, które wyznaczają ich cele życiowe, motywują do ich realizacji i ogólnie różnorakich działań, także w przestrzeni wychowania. Wychowanie ku wartościom jest rozpoznawaniem i uczeniem sensów oraz znaczeń. Dziecko poprzez codzienne życie w rodzinie jest wprowadzane $\mathrm{w}$ znaczenia, rozpoznaje $\mathrm{i}$ interpretuje otaczającą rzeczywistość poprzez nadawane jej znaczenia. Zarówno proces wychowania, jak i proces przebaczenia są istotowo powiązane $\mathrm{z}$ wartościami. Wychowanie do przebaczenia oznacza więc budzenie wrażliwości dziecka na drugiego człowieka.

Wychowanie poprzez wartości i wychowanie ku wartościom implikuje istotne mechanizmy wpływu wychowawczego. Wychowanie poprzez wartości eksponuje wzór osobowy rodzica, który prowadzi swe życie zgodnie z uznawaną hierarchią wartości. Z pedagogicznego punktu widzenia dotyczy to zagadnień związanych $\mathrm{z}$ metodą przykładu rodzica w wychowaniu dziecka. Wychowanie ku wartościom wskazuje na mechanizm wychowawczy zwany internalizacją lub inaczej nadawaniem znaczeń, a więc kształtowaniem systemu wartości u wychowanka i uwewnętrznieniem poznanych przyjętych zasad, norm, wartości. Obie klasy wpływów wychowawczych zachodzą jednocześnie.

12 Jarosław Horowski, Wychowanie moralne wedlug pedagogiki neotomistycznej (Torun: Wydawnictwo Naukowe Uniwersytetu Mikołaja Kopernika, 2015), 15.

13 Jadwiga Izdebska, Dziecko - dzieciństwo - rodzina. Kategorie pedagogiki rodziny w perspektywie pedagogiki personalistycznej (Białystok: NWSP, 2015), 206. 
Dla procesu wychowania do przebaczania oznacza to, że w wychowaniu rodzinnym fundamentalną sprawą jest po pierwsze własny przykład rodziców, a więc postawa wzajemnego przebaczenia w rodzinie. Na szczególne wyróżnienie zasługuje tu relacja małżeńska i przebaczenie w małżeństwie, jako przykład postawy przebaczenia i wzór do naśladowania dla dzieci. Po drugie w kontekście kształtowania hierarchii wartości dziecka, istotne jest kształtowanie szacunku do drugiego człowieka i nadanie znaczenia przebaczeniu, jako wartości samej w sobie i wartości w relacjach interpersonalnych.

\section{Zakończenie}

Jest faktem oczywistym, że problematyka przebaczenia jest interdyscyplinarna i w ramach różnych dyscyplin wielowątkowa. Spojrzenie filozoficzne i teologiczne pozwala poznać oraz zrozumieć istotę przebaczenia jako fenomenu ludzkiego. Rozpoznawanie przebaczenia jako aktu i procesu jest niezwykle istotne z punktu widzenia postępowania psychoterapeutycznego.

Pedagogiczna refleksja prowadzić zaś powinna, moim zdaniem, do analiz wychowania do przebaczenia i wychowania poprzez przebaczenie. Tak hasłowo sformułowany obszar poznania umiejscowiony w przestrzeni życia małżeńsko-rodzinnego integruje wiele interesujących poznawczo, użytecznych społecznie i w praktyce wychowawczej wątków. W tym znaczeniu ważne może być rozpoznawanie czy rekonstrukcja rodzinnych doświadczeń osób przebaczających i tych, którym przebaczono. Przebaczenie, jako akt i proces przynależący tylko człowiekowi, jest zjawiskiem intencjonalnym. Wymaga wnikliwości w poznaniu, opisie i wyjaśnianiu. Wszelkie próby analiz, zwłaszcza prowadzone w badaniach jakościowych, są niezwykle cenne dla pełniejszego rozumienia przebaczenia w obszarze wychowania w rodzinie.

W konkluzji nasuwa się ogólne spostrzeżenie, że przebaczenie, mimo wzrastającej liczby prac na ten temat, wciąż w pewnym sensie jest terra incognita, a w praktyce życia chyba jest nadal w jakimś stopniu cnotą zapomnianą.

\section{The Forgiveness in the Family - Pedagogical Implications (Summary)}

In the article, a pedagogical reflection on forgiveness is carried out in relation to upbringing in the family. The understanding of forgiveness was assumed as a process 
and attitude. In the analysis of issues, the reference is made to the system of values, the relations in the family and the importance of upbringing in creating an attitude. It is indicated that; on one hand, the life in the family should be characterized by the attitude of forgiveness, on the other hand, the upbringing in the family should create the attitude of forgiveness. Both issues were considered in the pedagogical view.

Key words: forgiveness; process; attitude; values; relation; upbringing; family.

\section{Przebaczenie w rodzinie - implikacje pedagogiczne (Streszczenie)}

W artykule pedagogiczna refleksja nad przebaczeniem prowadzona jest w odniesieniu do wychowania w rodzinie. Przyjęto rozumienie przebaczenia jako procesu i postawy. W analizie zagadnień odwołano się do systemu wartości, relacji wewnątrzrodzinnych i znaczenia wychowania w kształtowaniu postaw. Wskazano, że z jednej strony życie w rodzinie powinno odznaczać się postawą przebaczenia, $\mathrm{z}$ drugiej wychowanie $\mathrm{w}$ rodzinie winno kształtować postawę przebaczenia. Obie kwestie podjęto w pedagogicznej perspektywie.

Słowa kluczowe: przebaczenie; proces; postawa; wartości; relacja; wychowanie; rodzina.

\section{Bibliografia}

Braun-Gałkowska, Maria. Psychologia domowa. Lublin: Wydawnictwo KUL, 2008. Clendenen, Avis, Martin Troy. Uzdrawiająca siła przebaczania. Kraków: Wydawnictwo WAM, 2004.

Filozofia moralności. Wina, kara, wybaczenie, red. Jacek Hołówka. Warszawa: Fundacja Aletheia, 2000.

Horowski, Jarosław. Wychowanie moralne wedtug pedagogiki neotomistycznej. Toruń: Wydawnictwo Naukowe Uniwersytetu Mikołaja Kopernika, 2015.

Izdebska, Jadwiga. Dziecko - dzieciństwo - rodzina. Kategorie pedagogiki rodziny w perspektywie pedagogiki personalistycznej. Białystok: NWSP, 2015.

Król, Aldona. „Wychowanie do przebaczenia”. W: Wychowanie chrześcijańskie między tradycja a wspótczesnościa, red. Alina Rynio, 432-442. Lublin: Wydawnictwo KUL, 2007. 
Kübler-Ross, Elizabeth. Rozmowy o śmierci i umieraniu. Poznań: Media Rodzina, 1998.

Linn, Matthew, Dennis Linn. Uzdrawianie ludzkich zranień. Kraków: Wydawnictwo M, 1993.

Mellibruda, Jerzy. Pułapka niewybaczonej krzywdy. Warszawa: Instytut Psychologii Zdrowia i Trzeźwości, 1995.

Nowak, Marian. Pedagogiczny profil nauk o wychowaniu. Studium z odniesieniami do pedagogiki pielegniarstwa. Lublin: Wydawnictwo KUL, 2012.

Słownik Języka Polskiego, red. Mieczysław Szymczak. Warszawa: Wydawnictwo Naukowe PWN, 1996.

Tokarski, Stanisław. Od przebaczenia do pojednania - psychologiczne uwarunkowania pojednania z Bogiem i ludźmi. http://www.psychologia.net.pl/artykul. php?level=327 (pobrano: 15.06.2016).

Trepkowska, Elżbieta. „Dwie koncepcje przebaczenia. Przebaczenie jako warunek i jako element procesu naprawy relacji międzyludzkich". Etyka 42 (2009): 121-135.

Wilk, Józef. Pedagogika rodziny. Zagadnienia wybrane. Lublin: Wydawnictwo Poligrafia Salezjańska, 2002.

Wojcieszke, Bogdan. Człowiek wśród ludzi. Zarys psychologii społecznej. Warszawa: Wydawnictwo Naukowe SCHOLAR, 2002. 
